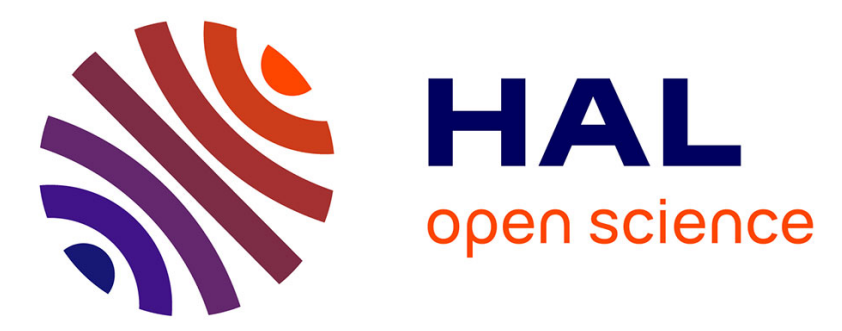

\title{
EXAFS Study of Oxygen Distortions in Gd2CuO4 as Function of Temperature and Pressure
}

\author{
G. Nowitzke, H. Meier, R. Lübbers, J. Dumschat, G. Wortmann
}

\section{To cite this version:}

G. Nowitzke, H. Meier, R. Lübbers, J. Dumschat, G. Wortmann. EXAFS Study of Oxygen Distortions in $\mathrm{Gd} 2 \mathrm{CuO} 4$ as Function of Temperature and Pressure. Journal de Physique IV Proceedings, 1997, 7 (C2), pp.C2-1023-C2-1024. 10.1051/jp4:19972126 . jpa-00255185

\section{HAL Id: jpa-00255185 https://hal.science/jpa-00255185}

Submitted on 1 Jan 1997

HAL is a multi-disciplinary open access archive for the deposit and dissemination of scientific research documents, whether they are published or not. The documents may come from teaching and research institutions in France or abroad, or from public or private research centers.
L'archive ouverte pluridisciplinaire HAL, est destinée au dépôt et à la diffusion de documents scientifiques de niveau recherche, publiés ou non, émanant des établissements d'enseignement et de recherche français ou étrangers, des laboratoires publics ou privés. 


\title{
EXAFS Study of Oxygen Distortions in $\mathrm{Gd}_{2} \mathrm{CuO}_{4}$ as Function of Temperature and Pressure
}

\author{
G. Nowitzke, H. Meier, R. Lübbers, J. Dumschat and G. Wortmann \\ Fachbereich Physik, Universität-GH Paderborn, 33095 Paderborn, Germany
}

\begin{abstract}
We studied the temperature and pressure dependence of the oxygen distortion in the $\mathrm{Cu}-\mathrm{O}$ planes of the $\mathrm{Gd}_{2} \mathrm{CuO}_{4}$ T-phase, employing the Gd-I III EXAFS.
\end{abstract}

\section{INTRODUCTION:}

Superconductivity and structural properties are closely related in the so-called 2-1-4 systems of tetragonal $\mathrm{La}_{2} \mathrm{CuO}_{4}$ (Tphase) or $\mathrm{Nd}_{2} \mathrm{CuO}_{4}$ ( $\mathrm{T}^{\prime}$-phase) type. In the n-doped $\mathrm{T}^{\prime}$-phase series, $\mathrm{RE}_{2-\mathrm{x}} \mathrm{M}_{\mathrm{x}} \mathrm{CuO}_{4}$ with $\mathrm{RE}=\mathrm{Nd}, \mathrm{Sm}, \mathrm{Eu}$ and $\mathrm{M}=\mathrm{Ce}, \mathrm{Th}$, superconductivity is observed, but not in the corresponding Gd-system. A possible reason for the absence of superconductivity is the distortion of the oxygen positions in the Cu-O planes, as evidenced by XRD studies [1], by Gd-155 Mössbauer effect [1,2] and by neutron scattering [3]. Here we studied in $\mathrm{T}^{4}$-phase $\mathrm{Gd}_{2} \mathrm{CuO}_{4}$ the temperature $(18 \mathrm{~K}-300 \mathrm{~K})$ and pressure (up to $4 \mathrm{GPa}$ ) dependence of the oxygen distortion in the $\mathrm{Cu}-\mathrm{O}$ planes employing the $\mathrm{Gd}-\mathrm{L}_{\mathrm{III}}$ and $\mathrm{Cu}-\mathrm{K}$ EXAFS [4].

\section{EXPERIMENTAL DETAILS, RESULTS AND DISCUSSION:}

The measurements were performed at the EXAFS-II beamline at HASYLAB (DESY, Hamburg) employing a Si(111) double crystal monochromator and a focussing Au mirror. The high-pressure studies were performed with a diamond-anvil cell and in-situ pressure determination employing the nuby fluorescence [4]. We found that the Gd- $\mathrm{L}_{\text {III }}$ EXAFS is more sensitive than the $\mathrm{Cu}-\mathrm{K}$ EXAFS to detect changes of the $\mathrm{O}(1)$ positions [5]. Due to the rather complex surrounding of $\mathrm{Gd}$ in the $\mathrm{Gd}_{2} \mathrm{CuO}_{4}$ structure (Fig. 1), multishell analyses of three $\mathrm{Gd}-\mathrm{O}$, one $\mathrm{Gd}-\mathrm{Cu}$ and one $\mathrm{Gd}-\mathrm{Gd}$ distance, including also all multiple scattering paths up to $4.8 \AA$, were employed using the FEFF 5.05 program [6].

Fig. 2a exhibits the multishell fits of the backtransformed $G d-L_{I I I} \chi(k)$ spectra at various temperatures and pressures. These fits are very sensitive to the $O(1)$ positions; only a splitting in two distances $G d-O(1)$ ' and Gd-O(1)" yielded excellent fits. From the two Gd-O(1) distances shown in Fig. $2 b$ one derives a distortion of the $O(1)$ positions in the $a-b$ plane from the tetragonal structure, which agrees perfectly with results of a recent neutron scattering study of $\mathrm{Gd}_{2} \mathrm{CuO}_{4}$ at $300 \mathrm{~K}$ [3]. Our EXAFS results demonstrate that the oxygen distortion is practical temperature independent, and therefore not connected with the magnetic ordering in the $\mathrm{Cu}-\mathrm{O}(1)$ planes around $270 \mathrm{~K}$. On the contrary, the distortion decreases strongly with pressure as shown in Fig. 2b. From an extrapolation one may conclude that the $\mathrm{O}(1)$ distortion disappears around $7 \mathrm{GPa}$ and may even speculate that superconductivity is observed at such pressures in $\mathrm{n}$-doped $\mathrm{Gd}_{2} \mathrm{CuO}_{4}$. We finally want to mention that the analysis of the second cumulants of the Gd- $\mathrm{L}_{\mathrm{III}}$ and $\mathrm{Cu}-\mathrm{K}$ EXAFS reveals a detailed picture of the anisotropic in-plane vibrations of the $O(1)$ oxygens.

Acknowledgements: - Work supported by the BMBF (Projekt 05-5PPACB-8)

\section{References:}

[1] P. Adelmann et al., Phys. Rev. B 46, 3619 (1992).

[2] M. Muther et al., Physica C 209, 428 (1993).

[3] M. Braden et al., Europhys. Lett. 25, 525 (1994).
[4] J. Röhler and R. Lübbers, HASYLAB Report 1993, p. 239 and 909.

[5] H. Meier, Diplomarbeit, Universität Paderborn (1995).

[6] J.J. Rehr et al., J. Am. Chem. Soc. 113, 5135 (1991). 

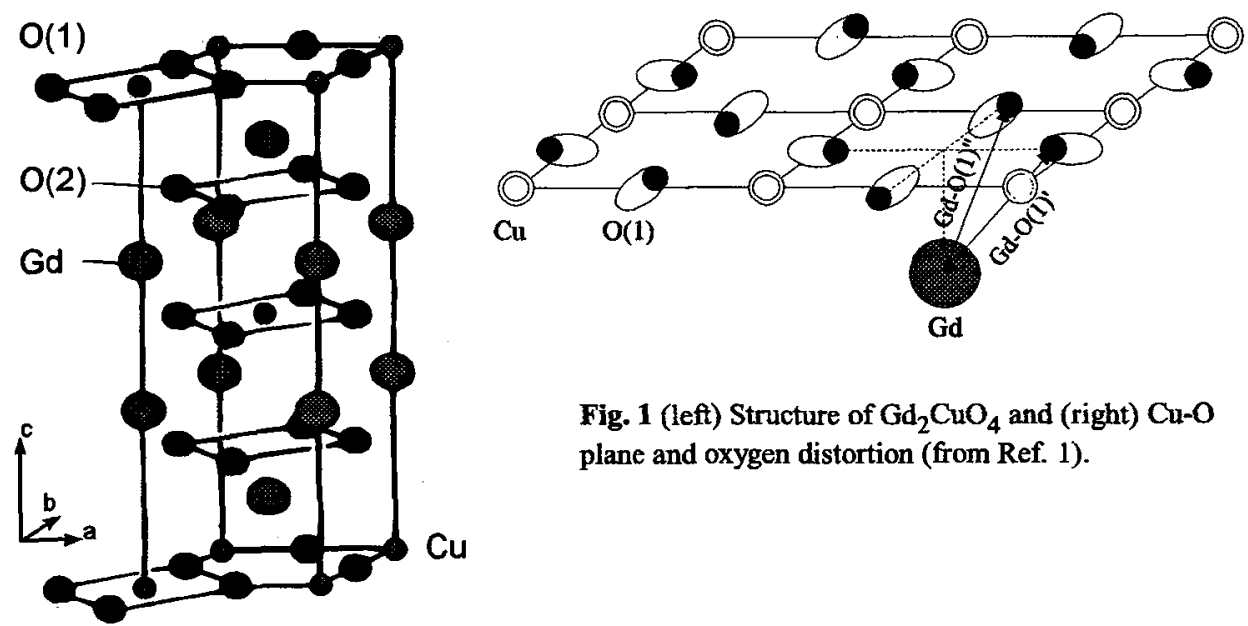

Fig. 1 (left) Structure of $\mathrm{Gd}_{2} \mathrm{CuO}_{4}$ and (right) $\mathrm{Cu}-\mathrm{O}$ plane and oxygen distortion (from Ref. 1).
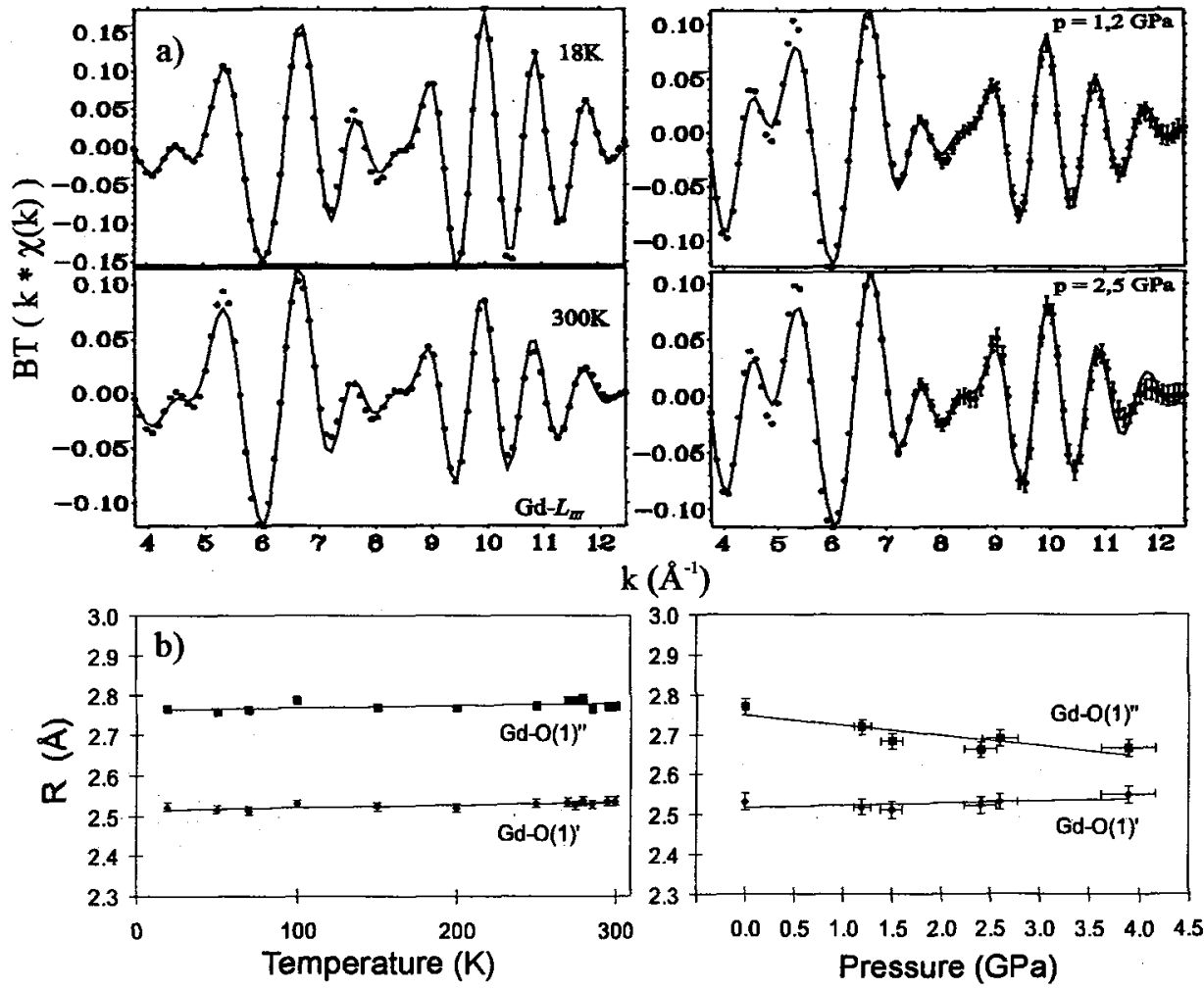

Fig. 2(a) (upper part): Backtransformed $\chi(\mathrm{k})$ spectra of $\mathrm{Gd}_{2} \mathrm{CuO}_{4}$ at various temperatures at ambient pressure (left) and at various pressures at room temperature (right). 2(b) (lower part): Temperature (left) and pressure (right) dependence of the Gd-O(1)' and Gd-O(1)" distances, reflecting the oxygen distortion in the $\mathrm{Cu}-\mathrm{O}(1)$ plane. 